\title{
APPROACHES AND STEPS IN ESP COURSE DESIGN
}

Muthmainnah

Universitas Al Asyariah Mandar, Indonesia

Like Raskova Octaberlina

Universitas Islam Negeri Maulana Malik Ibrahim, Malang, Indonesia

Nenni Dwi Aprianti Lubis

Universitas Sumatera Utara, Indonesia

\begin{abstract}
A B S T R A C T
This paper discusses how ESP (English for Specific Purposes) course design has developed into one of the most trending EFL teaching fields since the early 1960s. It's a phenomenon that has grown out of a number of other course designs. To date we have come across a huge range of course offers in the ESP field. each course has its own teaching area and has a design or approach to running the course. This paper aims to find out what kind of approach and design is contained or used in each ESP course that integrates all the needs of the course. It is about how to integrate the three components of needs analysis, PSA, TSA, and LSA, and integrated sources of data holders, students, teachers, and experts. Each step of the structured approach will integrate all the components required in an ESP course.
\end{abstract}

Keyword:

Approaches, Steps Course Design, English for Specific Purposes.

\section{Introduction}

According to Robinson, (1991), 'English for a specific purpose is now a major activity around the world. It is a company engaged in education and training and practice and has taken up three main areas of knowledge: language, pedagogy and specific areas of interest for students.'

In ESP we hope that learning from ESP can be a guide to all ESP residents. Today and in the future, the challenges and joys to be enjoyed are both challenges, difficulties to be avoided and difficulties to be avoided. The author wrote this paper, not only explaining reasons, but also presenting the itinerary that we shall follow.

Moreover, ESP is divided in several focus areas: ESP (EST) which is divided into English for Occupational Proposal (EAP), English for Medical Studies and English for Occupational Proposals (EAP). English for Business and Economics (EBE) is divided into English for Medical Studies and English for Occupational Proposal.

\section{Materials and Discussion}

\section{Approaches to Course Design}

Course design is the process by which the raw data on a need for learning is interpreted for an integrated series of experience in teaching-learning. The objective of the design of course is to bring the student to a specific state of knowledge. In practice this includes using available theoretical and empirical information for producing a curriculum, selecting, adjusting or writing of materials in line with the curriculum, developing a methodology to teach those materials and setting out evaluation procedures to measure progress towards the specified objectives. The ESP course design approach is probably numerous, as there are course designer approaches. However, three key types of course design can be identified: language-centered, skill centered and learning-centered.

A. Language-Centered Approach(performance)

This is the simplest kind of course design and is probably the one most familiar to English teacher. It is particularly prevalent in ESP. The language-centered course design process aims to draw as direct a connection as possible between analysis of the target situation and the content of the ESP course. 


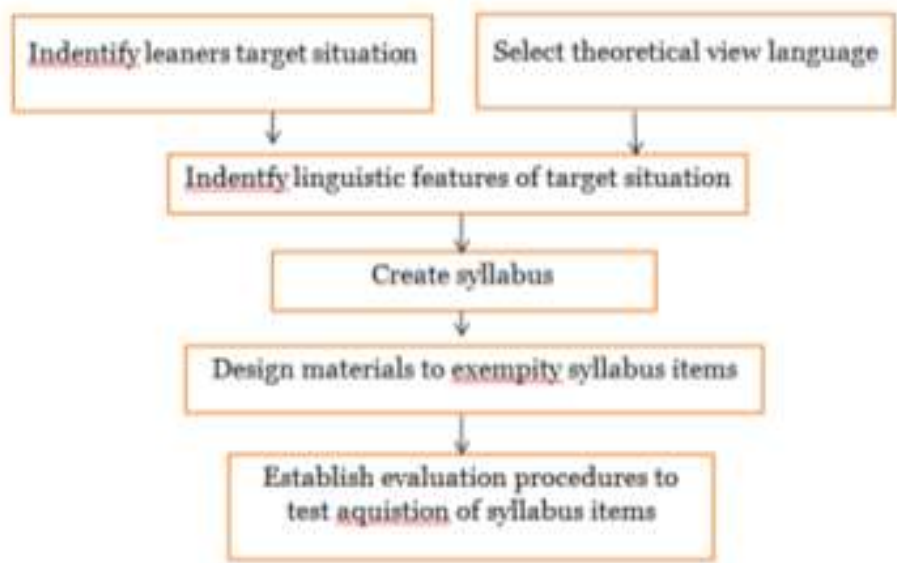

This will seem very rational at first sight. at first sight The student begins by learning the curriculum and then uses resources in the class, and eventually tests the mastery of the curriculum objects. The curriculum itself takes place at different stages. It has however a range of drawbacks that appear logical and straight forward:

- It begins with the students and their needs, and thus can be based on every significant sense of the word. The student is used simply to evaluate the objective condition. Installed as in general English, only a small portion of the target language is taught instead of taking the whole language and teaching it to the student. The student is only used to find the limited area. After that, the student doesn't play a further role. As we have shown, students should be considered at any phase of the process when evaluating need analysis. However, this model doesn't take account of the learning needs of the students. Therefore it is not based on learners but is clearly limited by learners.

- The learner-centre, also a rigid and inflexible procedure that can take no account of disagreements and inconsistencies inherent in any human endeavour, can be criticized. The course designer is stuck in a relentless loop once the initial analysis of the target condition is made. But what if the first interpretation is incorrect? What if some main factor, such as Mead's unexpected student motivation, is not taken into consideration? Flexibility, feedback mechanisms and error tolerance must be included in any procedures to respond to unforeseen influences or evolve.

- One of the appealing characteristics of this model is its systematic appearance. In doing so, however, it induces the false belief that systematic learning itself generates systematic learning in the learner by systematic examination and presentation. The role of systematization in learning is unfortunately not so easy. There are definitely many evidence to suggest that information systemisation plays a vital role in the learning process: by integrating individual pieces of knowledge into a meaningful prediction system. But the key point here is that it must be a system created internally and not a system implemented externally. The systemic analysis and systemic presentation of information in no way means that it will be learned systematically. The system must be relevant to the learner. And we must admit, sadly, that we don't know enough about the mind to construct its inner information structure. However, we must avoid the error of the Audiolingual approach that explaining this structure causes structural learning, since language has a system which can be represented.

- The language model does not consider variables that must play an unavoidable role in designing a course. Data generated by an examination of needs are by themselves not essential. Data must be interpreted and all forms of information that are not disclosed in the study itself must be used to interpret the data. The fact that an empirical model is used incorrectly as a predictive model is actually occurring in the language-centered way. To assess the contents of pedagogical programs and resources, an examination of what happens in a given case is used. But these behaviors are affected by all kinds of other variables. One of the primary principles of good pedagogical materials is to be interesting in a simple example. You would not know whether a text or an action is interesting if a study of language papers. So if content is based on languagecentric model, there are either other factors that are not recognized in the model or these factors are not considered significant, and, regrettably, so often. As an instructor said at a materials conference, 'It doesn't matter if it's dull. This is ESP." This is ESP.

- The objective situation analysis is just on a surface level, which is based on vocabulary. The skills that underline success show so little.

In summary, then, the logical, straightforward appeal of the language-centered approach is, in effect, its weakness. It fails to recognize the fact that, learners being people, learning is not straightforward, logical process.

\section{B. Skills-centered Approach course design}

The skills-centered approach to ESP has been widely applied in a number of countries, particularly in Latin America. Students in universities and colleges there have the limited, but important need to read subject texts in English, because they are unavailable in the other tongue. In response to this need, a number of ESP projects have 
been set up with the specific aim of developing the students' ability to read in English. The skills-centered approach is founded on two fundamental principles: Theoretical and Pragmatic.

a. The basic theoretical hypothesis is that underlying any language behavior are certain skills and strategies, which the learner uses in order to produce or comprehend discourse. A skills-centered approach aims to get away from the surface performance data and look at the competence that underlies the performance.

b. The pragmatics basis for the skills-centered approach derives from a distinction made by Widdowson (1981) between goal-oriented courses and process-oriented courses. Holmes (1982) points out that:'In ESP the main problem is usually one of time available and student experience.

Holmes puts his finger on a contradiction that arises from interpreting 'needs' in the narrow sense of 'target situation necessities'. If the ESP course is design in terms of goals, there is in effect a tacit admission that a large number of students will fail the course. Since ESP is by its very nature process that is intended to enable people to achieve a purpose, it is at best a little odd to frame the course in such a way as to almost predict failure. The process-oriented approach tries to avoid this problem by removing the distinction between the ESP course and the target situation. The ESP course is not seen as a self-sufficient unit from which learners emerge as proficient target situation performers, because, as Holmes points out, a number of students are unlikely to achieve this proficiency. Instead, the ESP course and target situation are seen as a continuum of constantly developing degrees of proficiency with no cut-off point of success or failure.

The process-oriented approach tries to avoid this problem by removing the distinction between the ESP course and the target situation. The ESP course is not seen as a self-sufficient unit from which learners emerge as proficient target situation performers, because, as Holmes points out, a number of students are unlikely to achieve this proficiency.

The role of need analysis in a skills-centered approach is twofold. Firstly, it provides a basis for discovering the underlying competence that enables people to perform in the target situation. Secondly, it enables the course designer to discover the potential knowledge and abilities that the learners bring to the ESP classroom.

The processes it is concerned with are the processes of language use not of language learning. It is with this distinction in mind that we turn to the third approach to course design.

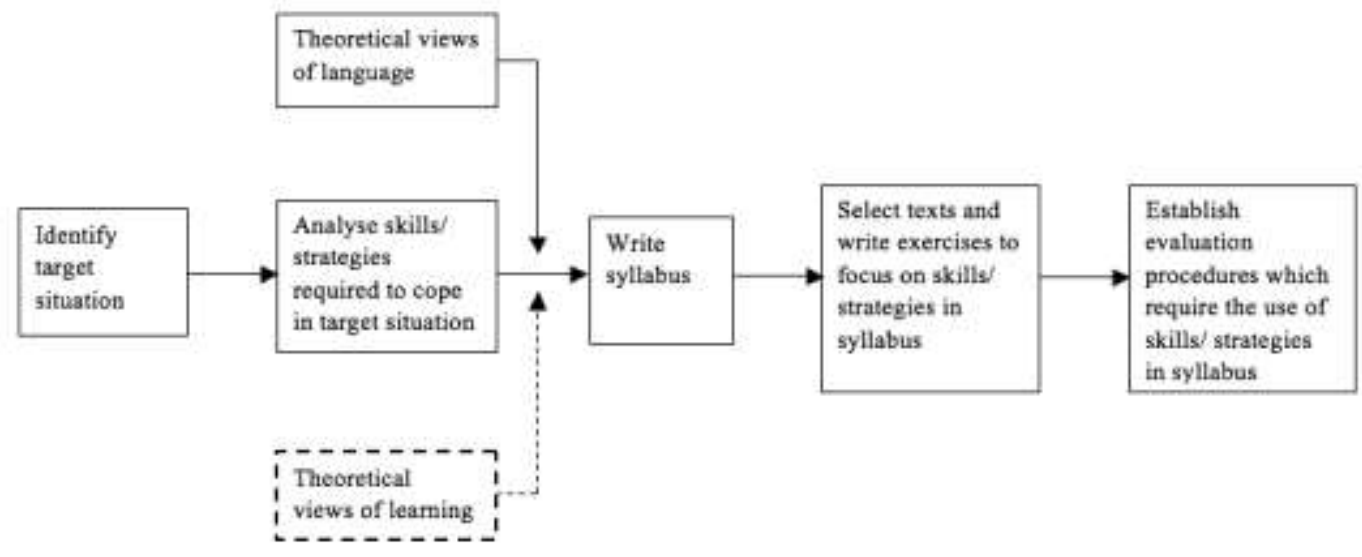

C. A learning-centered approach

The learner-centered approach is based on the idea that the learner decides the learner absolutely. As teachings, we can control what we teach, but only the students can decide what they understand. Learning is seen as a phase in which students use their experience or abilities to grasp the flow of new material. Therefore learning is an internecological process that depends critically on the awareness and enthusiasm of the students already. This view of learning is difficult to default if we actually see learning in the mind of the learner in terms of the end product. However, the context in which learning takes place can and should be seen. Learning is not merely a mental process, it is an individual-society negotiating process. The organization sets the target (in the case of ESP the target performance) and the people must make every effort to meet this target as close as possible to this target (or reject it). The students will undoubtedly decide their own direction to the goal at the time of their journey, but that does not make the goal unimportant. On potential paths, the objective still has a major impact. There's more to be considered in the learning process than the learner. That is why we oppose a learner-centered approach to a learning-centered approach, which demonstrates that learning is a priority. The student needs to be taken into 
account but not the only factor in the learning process. Thus the term: student-centered would be misleading for our intent.

In return to our discussion of the approach to the design of the course, we see that the approach concentrating on the learner does not completely consider the learner, since the ESP learning situation still depends too much on the target situation. The student is used to define and analyze the goals of the case. But then the student and the target situational analyzes are rejected as with the language-centered approach so that the quality of the course can be decided with no further regard to the student.

An approach based on the language says: this is the essence and will decide the ESP direction of the target situation. An approach based on skills says: it doesn't suffice. To find out which processes allow someone to succeed, we must look behind the target performance data. The ESP course will be decided by these methods. An approach that emphasizes on learning claims that this is still not enough. We need to look past the desire to exercise, since everyone is granted that ability. In this diagram we could see the relation:

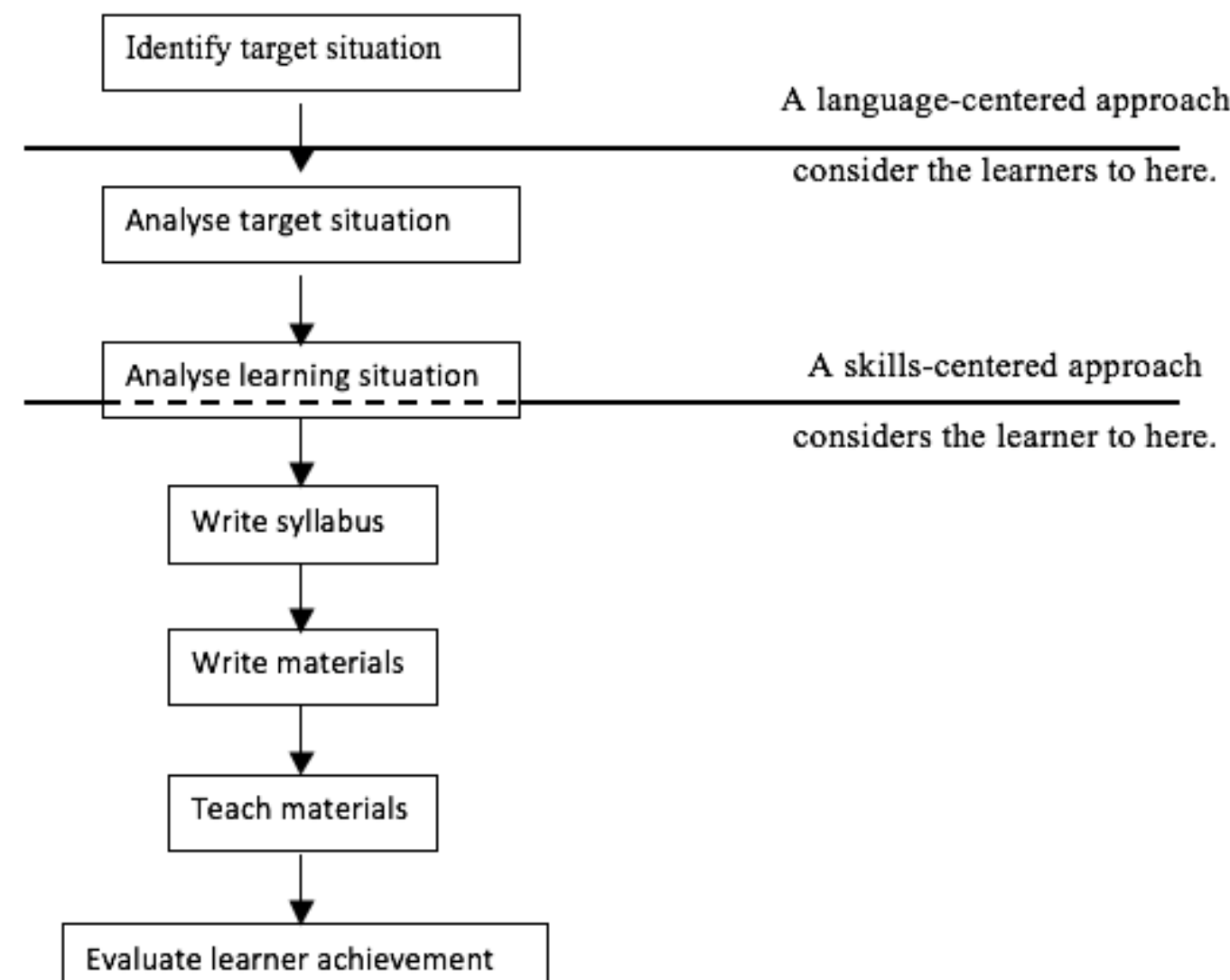

A learning-centred approach

\section{Must consider the learner At every stage.}

Figure : A comparison of approaches to course design

Figure it shows that a learning-centred approach to course design takes account of the learner at every stage of the design process. This has two implications:

a) Course design is a negotiated process. There is no single factor which has an outright determining influence on the content of the course. The ESP learning situation and the target situation will both influence the nature of the syllabus, materials, methodology and evaluation procedures. Similarly, each of these components will influence and be influenced by the others.

b) Course design is a dynamic process. It does not move in a linear fashion from initial analysis to completed course. Need and resources vary with time. The course design, therefore, needs to have built-in feedback channels to enable the course to respond to developments. The learning-centred course design process is shown in this diagram: 


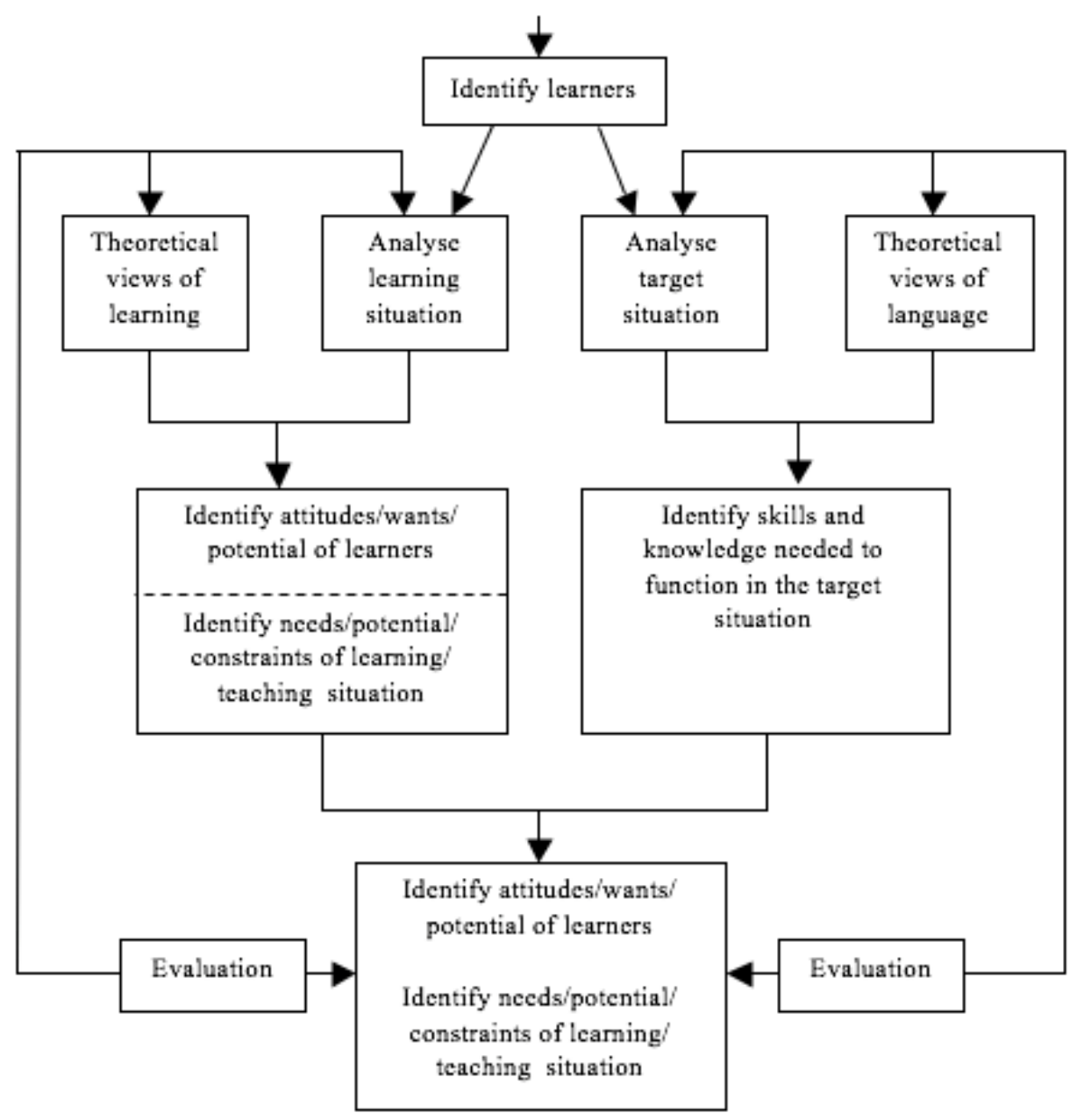

\section{Steps In ESP Course Design}

Course design is a process that consists of several steps. In this vein, Robinson (1991, p.34) believes that course design is the product of a dynamic interaction between the results of NA, the course designers' approach to syllabus and methodology, and existing materials. According to Graves (2000), a systematic course design consisting of six steps that are:

1. Conducting needs assessment and needs analysis

2. Determining the goals and objectives of the course.

3. Conceptualizing the content.

4. Selecting and developing materials and activities.

5. Organising the content and activities.

6. Evaluating 


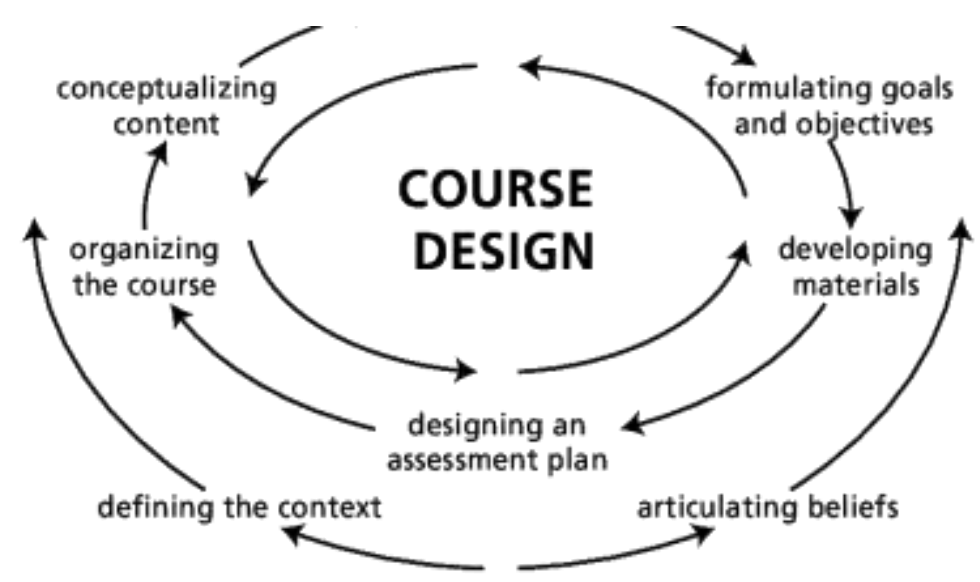

Graves' Model of Curriculum Development (From: Graves, 2000, p. 4)

1. Conducting Needs Analysis

Needs analysis is the first and fundamental process in designing syllabus. Although thereis no definitedefinition of ESP, all ESP schoolar agree that in designing an ESP course, needsanalysis must betaken as the first priority. Needs analysis provides the information learnerse ${ }^{\text {ee }}$ and targetse needs.

The information isbeneficial in drawing the goal and objectives of the teaching learning process. Ifneeds are clear,the learning aims can be expressed more easily and the language course canbecome motivating.The selection of tasks and materials can also be based on the results of theanalysis. The result of the analysis of the learners"e needs may give clear information of the tasks and material that may appeal them.

The needs analysis is also helpful in organising the content and activities since it identifies the sequence of real life activities that could be adopted in the teaching learning process. Knowing the stakeholders ${ }^{\text {ee }}$ needs can also be valuable in determining the standard of achievement in the assessment and evaluation process. In other words, all activities in designing syllabus are dependent on the needs analysis process and result.

2. Determination of Goals and Objectives of the Course

A goal is something that wanted to be achieved and in the case of language learning, goals. The goals and the objectives can be drawn from the results of the needs analysis. Since ESP was situated for the adult learners seeking for employment in the future, the goals and the objectives should relate to those needs. The analysis of the problems faced by the learners can also be considered in shaping the goals and objectives.

3. Content Conceptualization

The next process needed to be followed is conceptualizing the content; that is choosing and analyzing the necessary content related to the needs analysis and the goals and objectives. Reilly (1988, in Xeno dohidis, 2006) gives some practical guidelines to content choice and design. According to Relly, we need to:

- Define what the students should be able to do as exactly and realistically as possible, as the result of the instruction.

- Rank the syllabi in order of importance according to the desired outcomes;

- Evaluate available resources and match them with the syllabi;

- Designate one or two syllabi as dominant;

- Review how combination and integration of syllabus types can be achieved and in what proportion;

- And translate decisions into actual teaching units.

In this stage, we need to identify language function and language expression related tot he jobs. Language functions are things the speakers do with their language in communication.

4. Selection and Development of Materials and Activities

According to Graves (1996, in Xenodohidis, 2006), in order to select materials the following issues should be taken into account:

- $\quad$ Effectiveness in achieving the course purposes

- Appropriateness of the materials, so that the students will feel comfortable. This means that the material will be relevant to their interests and language level.

- Feasibility, so that the material will be in accordance with the studentse capabilities and the course will not prove too difficult for them. Choosing materials may mean development of new material, collection of various materials or adaptation of existing ones. The source of materials can be:

a. From published materials (textbooks, journals, magazines)

b. From real speech (lecturers, hotel communication, seminars)

c. Specially written 
d. Simplified and adapted from public materials or instances of real speech.

There are some suggestions given by Xenodohid is that beneficial for this stage. According to him, any task aimed at activities should enable the students to deal with situation related to their future employment. The lack of materials can be prevailed over by giving certain task related to the future task. Using semi authentic materials is suggested. More over, communication situations need to be involved since they give a different dimension to language.

5. Organization of Content and Activities Course

Organization is important since it provides the teacher and the students with a clear idea of what will be taught (Xenodohidis, 2006). In addition, Xenodohidis mentioned two principles under lying the concept of sequencing material; building and recycling. Building can follow the process of the simple to the more complex, from concrete to more open ended, while recycling means that the students deal with taught materials in a new way. Another way to consider course organization is as a cycle or as a matrix. In a cyclical approach, the teacher introduces a cycle of activities following a consistent sequence. In a matrix approach, the teacher works with some activities and as time passes, decides with which ones to continue (Graves, 1996, in Xenodohidis, 2006). The content and activities may also be sequenced based on the standard operational procedure (SOP) of the related job. The tasks performed in each duty need to be identified. Those identified tasks are then sequenced based on the operational procedure. The sequenced tasks are again analysed to reveal the language functions and language expression needed for those tasks. Certain information related to the culture understanding and standard performance required for those tasks can also be assessed and analysed. This approach is known as Task-Based Approach (TBA).Task based approach to language teaching is a recent view which is based on the findings of linguist and psychologist. This approach is against traditional approaches such as PPP(presentation, practice, production) model of teaching (Foster, 1999, in Songhori, 2006). Task based syllabus which is the corner stone of TBA is defined by Richards, et.al. (1991, in Songhori,2006) as: "a syllabus which is organised around TASKs, rather than in terms of grammar or vocabulary.

6. Assessment and Evaluation

The final stage in ESP course design is concerned with evaluating the results of implementing the previous stages. Hence, it is indispensable for both ESP teachers and learners to determine whether their aims and objectives were attained or not. Dudley -Evans and St. John (1998, p.13) define evaluation as "a process which starts with the specification of what information to be collected and which ends with the production of changes in the present activities or future ones." In fact, evaluation stage attempts to reveal the learners' progress and to what extent the course was effective. Moreover, it can detect the aspects that were not successfully covered in the learning situation. Hutchinson and Waters (1987) propose two levels of evaluation mainly: "learners' assessment" and "course evaluation".

\section{Conclusion}

The method of designing courses is to view the raw data on a learning requirement to create an integrated number of learning experiences. All the criteria of the course are incorporated in ESP. The incorporation of three elements: PSA (present situation. analysis), TSA (target situation analysis), and LSA, as well as integrated sources of data holdings, students, teachers and experts. The three components of need analysis are integrated in the analysis. ESP, course, assume to have several different approaches: language-centered, skill-centered and learning-centered. For example, if we are trying to design an ESP course using a Learning Based approach, this will mean that what is accomplished is fully decided by the learner, even though professors will influence the teaching, but what is learned When we want to do an ESP course, we need to understand which approach you want to apply to this course and how this course is planned.

\section{References}

Dudley-Evans, T., and M. J. St. John, Developments in English for Specific Purposes, Cambridge: Cambridge University Press, 1998.

Graves,K. Designing Language Course. Boston:Heinle\& Heinle,2000.

Hutchinson, T., and A. Waters, English for Specific Purposes: A learning-centred Approach, Cambridge: Cambridge University Press, 1987.

Harmer, Jeremy, The Practice of English Language Teaching, London: Longman, 1991.

Day, H. and Krzanowski, M. (2011). Teaching English for Specific Purposes: An Introduction.Cambridge, UK. Cambridge University Press.

Munby, J., Communicative Syllabus Design, Cambridge: Cambridge University Press, 1987.

Richard, Jack C., Communicative Language Teaching Today, Cambridge University Press, 2006.

Robinson, P., ESP (English for Specific Purposes), Pergamon, 1980.

Strevens, P., ESP after twenty years: A re-appraisal, In M. Tickoo (Ed.), ESP: State of the art (1-13). SEAMEO Regional Language Centre, 1988.

Sysoyev, P., Developing an English for Specific Purposes Course Using a Learner Centered Approach: A Russian Experience, The Internet TESL Journal, Vol. VI, No.3, March 2000 http://iteslj.org/, 2000. 
Azazel,

7APPROACHES

TO

COURSE

DESIGN

EED,2016.

https://espeed2016.blogspot.com/2016/06/chapter-7-approach-to-course-design.html/

(accessed

January,12,2021)).

Asrifan, A. (2009). Using songs in teaching English language for the young learners. ParePare: unpublished.

Puasa, K., Asrifan, A., \& Chen, Y. (2017). Classroom Talk in Bilingual Class Interaction. Research in Pedagogy, 7(1), 106121.

Nadirah, N., Tahir, M. H., \& Asrifan, A. (2019). THE ABILITY TO TRANSLATE ENGLISH PHRASES INTO INDONESIAN AND THE DIFFICULTIES FACED BY THE ELEVENTH GRADE STUDENTS OF SMAN 1 PANCARIJANG. JOURNAL OF ADVANCED ENGLISH STUDIES, 2(1), 41-46.

Apdy, A. P. R., \& Asrifan, A. (2019, April). The Chinese mime game in teaching vocabulary on EFL classroom. In PROCEEDINGS OF THE 65th TEFLIN INTERNATIONAL CONFERENCE (Vol. 65, No. 01).

Taslim, T., Asrifan, A., Chen, Y., \& Nurdania, N. R. (2019). CORRELATION BETWEEN STUDENT'S VOCABULARY MASTERY AND SPEAKING SKILL. JOURNAL OF ADVANCED ENGLISH STUDIES, 2(2), 65-76.

Muthmainnah, M., Asrifan, A., Al Yakin, A., \& Sahabuddin, C. (2019, April). The use of dictogloss technique on ELT classroom: An experiment study of students listening comprehension. In PROCEEDINGS OF THE 65th TEFLIN INTERNATIONAL CONFERENCE (Vol. 65, No. 01).

Mutmainnah, M., Azis, S., Maulidya, U., \& Asrifan, A. (2017). Glory Style in Mandar Song Lyrics: A study of Mandar Tribe in South Sulawesi, Indonesia. JOURNAL OF ADVANCES IN LINGUISTICS, 8(1), 1286-1291.

Asrifan, A., Rinantanti, Y., Tang, S., \& Nadirah, N. (2019). THE 3-DIMENSION PICTURES IN INCREASING THE STUDENTS ABILITY AND INTEREST TO WRITE DESCRIPTIVE COMPOSITION. JOURNAL OF ADVANCED ENGLISH STUDIES, 2(1), 19-30.

Asrifan, A., Nadira, N., \& Haedar, H. (2018). IMPROVING STUDENTS'READING COMPREHENSION OF DESCRIPTIVE TEXT THROUGH COLLABORATIVE MURDER. JOURNAL OF ADVANCED ENGLISH STUDIES, 1(2), 21-31.

Asrifan, A. (2015). Analysis of English Students' Learning Style in Bilingual Class. International Journal of Literature and Arts, 3(4), 34

Farahdiba, S., \& Asrifan, A. (2016). Speaking Ability and Psychological Barriers of the Second Year Students of Hotel Department of SMKN 1 Sidenreng Kabupaten Sidrap in Speaking English. Asian EFL Journal, (89), 41.

Asrifan, A. (2012). Increasing the Students Ability to Write Descriptive Composition at SMP Negeri 13 Parepare by using the 3-Dimension Pictures.

Tang, S., Asrifan, A., Chen, Y., Haedar, H., \& Agussalim, M. (2019). THE HUMOR STORY IN TEACHING READING COMPREHENSION. JOURNAL OF ADVANCED ENGLISH STUDIES, 2(2), 77-87.

Nurwanti, N., Asrifan, A., \& Haedar, H. (2019). THE APPLICATION OF COOPERATIVE LEARNING: JIGSAW II TECHNIQUE IN IMPROVING STUDENTS'READING COMPREHENSION OF EXPOSITORY TEXT. JOURNAL OF ADVANCED ENGLISH STUDIES, 2(1), 31-40.

Asrifan, A. (2016). The Effectiveness of Think-Pair-Share Technique in Improving Studentsâ€ $€^{\text {TM }}$ Speaking Ability and Interest. English Literature and Language Review, 2(3), 24-35.

Asrifan, A., Muthmainnah, M., Al-Yakin, A., Sahabuddin, C., \& Haedar, H. (2018). THE CAUSE-EFFECT TECHNIQUE IN TEACHING RECOUNT WRITING. JOURNAL OF ADVANCED ENGLISH STUDIES, 1(2), 63-72.

Asrifan, A., Vargheese, K. J., Syamsu, T., \& Amir, M. (2020). ESP COURSE DESIGN: THE NEED ANALYSIS ON TOURISM DEPARTMENT IN INDONESIA VOCATIONAL HIGH SCHOOLS. JOURNAL OF ADVANCED ENGLISH STUDIES, 3(2), 69-77.

Asrifan, A., Ghofur, A., \& Azizah, N. (2020). Cheating Behavior in EFL Classroom (A Case Study at Elementary School in Sidenreng Rappang Regency). OKARA: Jurnal Bahasa dan Sastra, 14(2), 279-297.

Nadirah, N., Asrifan, A., Vargheese, K. J., \& Haedar, H. (2020). INTERACTIVE MULTIMEDIA IN EFL CLASSROOM: A STUDY OF TEACHING READING COMPREHENSION AT JUNIOR HIGH SCHOOL IN INDONESIA. JOURNAL OF ADVANCED ENGLISH STUDIES, 3(2), 131-145.

Muthmainnah, A. R., Atmowardoyo, H., Salija, K., \& Asrifan, A. (2020). Literary Work as Teaching Materials: A Study of Students and Lecturers Needs Analysis. Solid State Technology, 63(5), 394-407.

Tilome, A. A., Agustang, A., Jasruddin, M. S., \& Asrifan, A. (2020). Social Exchange of Political Elites in the Regional Leader Election of Gorontalo Province, Indonesia. Solid State Technology, 63(5), 521-531.

Pacinongi, A., \& Asrifan, A. (2020). Bimbingan Pengawas Berkelanjutan dalam Mewujudkan Pendidikan Karakter Bangsa dalam Kegiatan Belajar Mengajar Penjaskes. Celebes Education Review, 2(1), 1-7.

Gunawan, G., \& Asrifan, A. (2020). Penerapan Kerja Kelompok Kegiatan MGMP Guru Ekonomi dalam Menyusun RPP untuk Meningkatkan Kompetensi Pedagogik. Celebes Education Review, 2(1), 31-36.

Yusuf, I., \& Asrifan, A. PENINGKATAN AKTIVITAS KOLABORASI PEMBELAJARAN FISIKA MELALUI

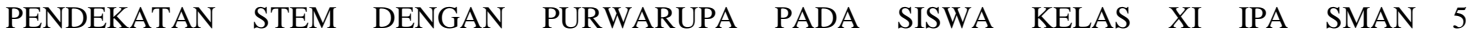
YOGYAKARTA. Editorial Team, 32.

Al Yakin, A., Sahabuddin, C., Rahayu, A., Fitrah, N., \& Arifin, M. (2020). Political Celebrification and Electability: A Study of Political Phenomena Imaging in Election Polewali Mandar District, West Sulawesi, Indonesia. Solid State Technology, 63(5), 632-646.

Junaedah, S. B. T., \& Ahmad, M. A. (2020). The Outdoor Learning Modules Based on Traditional Games in Improving 
Prosocial Behaviour of Early Childhood. International Education Studies, 13(10).

Octaberlina, L. R., \& Muslimin, A. I. (2020). Efl students perspective towards online learning barriers and alternatives using moodle/google classroom during covid-19 pandemic. International Journal of Higher Education, 9(6), 1-9.

Octaberlina, L. R., \& Anggarini, I. F. (2020). Teaching vocabulary through picture cards in Islamic Elementary School: a case study in Nida Suksa School, Thailand. Jurnal Madrasah, 13(1), 26-38.

Octaberlina, L. R. (2016). Plagiarism in English language theses in Indonesia. Jurnal Ilmu Pendidikan, 14(3).

Octaberlina, L. R., \& Anggarini, I. F. (2020). Teaching vocabulary through picture cards in Islamic Elementary School: a case study in Nida Suksa School, Thailand. Jurnal Madrasah, 13(1), 26-38.

Asrifan, A., Zita, C. T., Vargheese, K. J., Syamsu, T., \& Amir, M. (2020). THE EFFECTS OF CALL (COMPUTER ASSISTED LANGUAGE LEARNING) TOWARD THE STUDENTS'ENGLISH ACHIEVEMENT AND ATTITUDE. JOURNAL OF ADVANCED ENGLISH STUDIES, 3(2), 94-106.

Asrifan, A. (2021). ACADEMIC WRITING. LawArXiv. January, 2. https://doi.org/10.31228/osf.io/x2s7e

Asrifan, A. (2020). TUTORIAL PENGGUNAAN QUIZIZZ (www. quizizz. com) PADA PEMBELAJARAN. https://doi.org/10.31219/osf.io/kqnza

Asrifan, A. (2021). Abd Ghofur.“. THE USE OF READING CIRCLES IN INCREASING STUDENTS SPEAKING ABILITY AT THE ELEVENTH GRADE SMK NEGERI, 1. https://doi.org/10.31219/osf.io/8vjxy

Asrifan, A. (2020). Pandemic, Humanity and Education. https://doi.org/10.31219/osf.io/q2gpk

Asrifan, A. (2021). USING CAT AND MOUSE GAME TO IMPROVE STUDENT'S SPEAKING ABILITY AT THE ELEVENTH GRADE OF MA YMPI RAPPANG. https://doi.org/10.31219/osf.io/phtvn

Asrifan, A., \& Ghofur, A. (2021). THE USE OF READING CIRCLES IN INCREASING STUDENTS SPEAKING ABILITY AT THE ELEVENTH GRADE SMK NEGERI 1 PANCARIJANG. https://doi.org/10.31219/osf.io/8vjxy

Asrifan, A. (2021). Book Review: Halliday. 1989. Spoken and Written Language. Oxford University Press. https://doi.org/10.31219/osf.io/ej8tb

Asrifan, A., \& Ghofur, A. (2021). TALK, ACTION, SILENCE, INTERRUPTION AND THEIR IMPLICATIONS IN BUGINESE SOCIETY (SOPPENG REGENCY). https://doi.org/10.31219/osf.io/pv3ku

Asrifan, A. (2020). PENILAIAN BERBASIS ANDROID MENGGUNAKAN APLIKASI PLICKERS. https://doi.org/10.31219/osf.io/htreq

Haulussy, R. H., Najamuddin, I. R., \& Agustang, A. D. M. P. (2020). The sustainability of the Sasi Lola tradition and customary law (Case study in Masawoy Maluku, Indonesia). Intl J Sci Technol Res, 9(2), 5193-5195.

Arwan, A., Agustang, A., Arlin, A., Yani, A., \& PUTRA, D. M. (2019). Contestation of Elite Discourse in Treatment of HIV and AIDS. Iranian Journal of Public Health, 48(12), 2205.

Mutiara, I. A., Agustang, A., Adam, A., Upe, A., \& Equatora, M. A. (2020). The dynamics of prostitutes lives in metropolitan cities. Journal of Critical Reviews. https://doi. org/10.31838/jcr, 7, 165.

Usman, A., Agustang, A., Djalal, D., \& Annas, S. (2018, October). The Contribution Of Supporter Community In Maximizing Their Role For The Advancement Of Makassar Football Club (PSM). In 1st International Conference on Social Sciences (ICSS 2018). Atlantis Press.

Ma'na, P., Agustang, A., Salusu, J., Ikhsan, A., \& Dirawan, G. D. (2015). Decision making strategic value based local wisdom Tongkonan North Toraja. Man India, 95(3), 633-639.

Dirawan, G. D. FOSTERING COLLABORATION STREET CHILDREN IN MAKASSAR. Man In India, 95(3), 569-576.

Abdurachman, A. D. M. P. A., \& Agustang, A. Culture Of Shame-Heart And Social Solidarity Of Kaitetu People Central Maluku District, Indonesia.

Aida, K. N., Agustang, A., Arlin, A., \& Agustang, A. D. M. The Patron-Client Relationship Patterns In Siwa Lima Fishermen Community, Aru Islands District Maluku, Indonesia.

Pannyiwi, R., Agustang, A., Kasnawi, T., Pada, A. T., Yani, A., \& Syam, S. (2020). Social Network for Drug Circulation in Sidenreng Rappang Regency, Indonesia. Systematic Reviews in Pharmacy, 11(9), 575-577.

Upe, A., Salman, D., \& Agustang, A. (2019). The effects of the exploitation of natural resources towards risk society construction in Southeast Sulawesi Province, Indonesia. Journal of Degraded and Mining Lands Management, 6(2), 1587.

Matakena, F., Watloly, A., Agustang, A., Adam, A., \& Alim, A. (2020). The Self-Concept of Ale Rasa Beta Rasa in the Orang Basudara Community in Ambon (Studies on the Community of Passo and Batumerah Country). International Journal, 9, 1307.

Asmi, A. S., Kasnawi, M. T., Agustang, A., \& Yani, A. (2020). Sociocultural Transformation in Efforts to Reduce Mortality of Infants in Bone Regency, Indonesia. Systematic Reviews in Pharmacy, 11(10), 762-765.

Usmana, A., \& Agustangb, A. The Implementation of “Arif” Social Behaviour within Perssin Supporters in Sinjai District.

Hasan, I. R., Agustang, A., Kahar, F., \& Tahir, H. (2019). Super Service Delivery”: an advanced conceptual model of onestop service for wide administrative region. Problems and perspectives in management, (17, Iss. 1), 189-201.

Asrifan, A. (2021). ISSUES IN TEFL “International Article Summary \& Presentation": Students' Reactions to School Based Oral Assessment: Bridging the Gap in Malaysia. https://doi.org/10.31228/osf.io/te3m5

Asrifan, A., Al Yakin, A., \& Sahabuddin, C. The Use of Dictogloss Technique on ELT Classroom: An Experiment Study of Students Listening Comprehension.

Octaberlina, L. R., \& Asrifan, A. (2021). THE USE OF HUMOR STORY IN IMPROVING THE STUDENTS'READING COMPREHENSION. https://doi.org/10.31219/osf.io/kvsbe 
Octaberlina, L. R., \& Asrifan, A. (2021). THE TEXT-BASED CHARACTER IN TEACHING READING COMPREHENSION AT THE TENTH GRADE STUDENTS. https://doi.org/10.31219/osf.io/p53sn

Asrifan, A. (2021). CODE MIXING AND CODE SWITCHING IN THE EFL CLASSROOM INTERACTION. https://doi.org/10.31228/osf.io/xd45c

Asrifan, A. (2021). ADVANCED GRAMMAR “Adverbs and Adverb Clauses”. https://doi.org/10.31228/osf.io/cuh83

Asrifan, A. (2020). TUTORIAL PENGGUNAAN QUIZIZZ (www. quizizz. com) PADA PEMBELAJARAN. https://doi.org/10.31219/osf.io/kqnza

Asrifan, A., \& Aeni, N. Book Review: I SPEAK FIVE LANGUAGES: FOSTERING PLURILINGUAL COMPETENCE THROUGH LANGUAGE AWARENESS By: Oliveira and Helena, Maria. https://doi.org/10.31228/osf.io/tjnq9

Asrifan, A. (2021). Modul Perkuliahan RESEARCH ON ENGLISH LANGUAGE TEACHING. https://doi.org/10.31219/osf.io/5rgvc

Asrifan, A. (2021). IMPROVING STUDENTS'SPEAKING ABILITY BY USING HAND DOLLS OF THE ELEVENTH GRADE STUDENTS OF MA YMPI RAPPANG. https://doi.org/10.31219/osf.io/zfhqu

Asrifan, A., Octaberlina, L. R., \& Handayani, R. (2021). SEMANTIC ANALYSIS ON THE USE OF ENGLISH LANGUAGE SLOGAN. https://doi.org/10.35542/osf.io/vtx5y

Asrifan, A. (2021). Book Review KONSTRUKSI GROUNDED TEORI Petunjuk Praktis Dalam Analisa Kualitatif Written By: Kathy Charmez. https://doi.org/10.31228/osf.io/nt8yk

Qisti, N., Nurwidah, A., Muslimin, I., \& Asrifan, A. (2020). THE EFFECT OF TEMPERATURE AND TIME DRYING TOWARD ORGANOLEPTIC QUALITY OF THE DUCKS BONE MEAL. Solid State Technology, 63(6), 1965219659.

Asrifan, A., \& Ghofur, A. Book Review: Writing for Academic Journals Second Edition. https://doi.org/10.31219/osf.io/su3ya

Andi Asrifan, N. (2020). THE TEXT-BASED CHARACTER IN TEACHING READING COMPREHENSION AT THE TENTH GRADE STUDENTS OF SMAN 4 SENRENG RAPPANG. Sarwah: Journal of Islamic Civilization and Thought, 18(02), 33-51.

Octaberlina, L. R., \& Asrifan, A. (2021). THE USE OF HUMOR STORY IN IMPROVING THE STUDENTS'READING COMPREHENSION.

Agustang, A., Mutiara, I. A., \& Asrifan, A. (2021). Genealogi Stigma Sosial Terhadap Pasien Covid 19. https://doi.org/10.31219/osf.io/ep7jf

Agustang, A., Ahriani, A., \& Asrifan, A. (2021). MARGINALISASI BUDAYA (STUDI PADA PRANATA SOSIAL MASYARAKAT MUSLIM SUKU KOKODA KOTA SORONG). https://doi.org/10.31219/osf.io/942y8

Agustang, A., Ariani, A. I., \& Asrifan, A. (2021). KONSTRUKSI SOSIAL JANDA TEREKSPLOITASI (STUDI KASUS DI KELURAHAN TETEBATU KECAMATAN PALLANGGA KABUPATEN GOWA).

Asrifan, A. (2021). APLIKASI DAN IMPLIKASI BERPIKIR SISTEMIK (SYSTEMIC THINKING) DALAM KEHIDUPAN.

Asrifan, A. (2021). PSIKOLOGI BELAJAR/TEORI BELAJAR: IMPLIKASI DAN HARAPAN.

Asrifan, A. (2021). PENDALAMAN MATA KULIAH SOCIOLINGUISTICS VARIASI SOSIAL PENGGUNA BAHASA.

Agustang, A. (2021). INTERAKSI SOSIAL KOMUNITAS LOKAL DENGAN PENDATANG DAN PERUBAHAN STRUKTUR KOMUNITAS LOKAL (Studi pada Masyarakat Majemuk di Kawasan Industri Makassar).

Agustang, A. (2021). KESEJAHTERAAN PSIKOLOGIS (studi Pada Dewasa Madya Yang Belum Menikah Di Kota Makassar).

Amelia, S., Lubis, N. D. A., \& Balatif, R. (2020). MIKROORGANISME DAN BAHAN PANGAN. Penerbit Qiara Media.

Amelia, S., Lubis, N. D. A., Siregar, M. A., \& Rozi, M. F. (2018). Research Article Antimicrobial Effect of Wasabia japonica or Wasabi on Raw Salmon in Served Sashimi at Japanese Restaurants in Medan.

Nasution, I. K., Lubis, N. D. A., Erwin, I., \& Nusa, M. I. (2018). Cognitive Function Differences based on Hemispheric Lesions of First-Ever Ischemic Stroke Patients. Ethnicity, 31, 44-30.

Lubis, N. D. A., Amelia, S., \& Balatif, R. (2020). Microbial Content Test on Sliced Papaya in Area of Universitas Sumatera Utara. Journal of Saintech Transfer, 3(2), 86-92.

Lubis, N. D. A., \& Sari, M. I. (2016, December). Body Mass Index and Triglyceride Levels of the Students of Faculty of Medicine University of North Sumatra 2016. In 1st Public Health International Conference (PHICo 2016). Atlantis Press.

Lubis, N. D. A., \& Lubis, H. A. P. (2016). Korelasi Indeks Massa Tubuh dengan Kebugaran Kardiorespirasi pada Siswa SMA Sutomo 2 Medan.

Lubis, N. D. A., Panggabean, M., \& Ichwan, M. (2020, November). Penguatan Sumberdaya Keluarga Dalam Mempercepat Perbaikan Gizi Masyarakat. In Talenta Conference Series: Agricultural and Natural Resources (ANR) (Vol. 3, No. 2).

Nasution, I. K., Lubis, N. D. A., Amelia, S., \& Hocin, K. (2018, March). The correlation of pain intensity and quality of life in chronic LBP patients in Adam Malik general hospital. In IOP Conference Series: Earth and Environmental Science (Vol. 125, No. 1, p. 012183). IOP Publishing.

Kusnadi, J. (2018). Pengawet Alami untuk Makanan. Universitas Brawijaya Press.

Amelia, S., Lubis, N. D. A., Balatif, R., Rozi, M. F., \& Sidhi, S. P. (2020, January). Antibacterial effect of Andaliman 
(Zanthoxylum acanthopodium) against contaminant in raw common carp (Cyprinus carpio Linnaeus). In IOP Conference Series: Earth and Environmental Science (Vol. 425, No. 1, p. 012036). IOP Publishing.

Amelia, S., Lubis, N. D. A., Rozi, M. F., \& Nababan, I. F. F. (2018, November). Safe processing method and storage time threshold for consuming of powdered-infant formula based on total plate count test. In IOP Conference Series: Earth and Environmental Science (Vol. 205, No. 1, p. 012033). IOP Publishing.

Amelia, S., Lubis, N. D. A., Siregar, M. A., \& Rozi, M. F. (2018). Research Article Antimicrobial Effect of Wasabia japonica or Wasabi on Raw Salmon in Served Sashimi at Japanese Restaurants in Medan.

Rosli, M. H. (2018). Korelasi Antara Status Gizi dan Status Anemia Terhadap Indeks Prestasi (IP) Mahasiswa Malaysia yang Studi di Universitas Sumatera Utara.

Lubis, N. D. A., \& Sari, M. I. (2016, December). Body Mass Index and Triglyceride Levels of the Students of Faculty of Medicine University of North Sumatra 2016. In 1st Public Health International Conference (PHICo 2016). Atlantis Press.

Lubis, N. D. A., Nasution, T. A., Wahyuni, D. D., \& Feriyawati, L. (2020, November). Gambaran Umum Status Kesehatan Siswa SDN 040494 Susuk Kecamatan Tiganderket, Kabupaten Karo. In Talenta Conference Series: Agricultural and Natural Resources (ANR) (Vol. 3, No. 2).

Lubis, N. D. A., Amelia, S., \& Balatif, R. (2020). Microbial Content Test on Sliced Papaya in Area of Universitas Sumatera Utara. Journal of Saintech Transfer, 3(2), 86-92.

LUBIS, N. D. A., NASUTION, T. A., \& PERMALU, R. K. LACK OF NUTRITION PROBLEM AMONG PRIMARY SCHOOL PUPILS IN MEDAN MUNICIPALITY.

Amelia, S., Lubis, N. D. A., \& Balatif, R. (2020). Coliform Quality Test on Tofu Samples in Three Markets in Medan City. Systematic Reviews in Pharmacy, 11(5), 619-623.

Yusraini, E., \& Lubis, N. D. A. (2020). Partial properties of young corn flour based on particle size and its effect on textu re and sensory acceptability of biscuit. E\&ES, 454(1), 012117.

Amelia, S., Lubis, N. D. A., Balatif, R., Rozi, M. F., \& Sidhi, S. P. (2020, January). Antibacterial effect of Andaliman (Zanthoxylum acanthopodium) against contaminant in raw common carp (Cyprinus carpio Linnaeus). In IOP Conference Series: Earth and Environmental Science (Vol. 425, No. 1, p. 012036). IOP Publishing.

Amelia, S., Lubis, N. D. A., Rozi, M. F., \& Nababan, I. F. F. (2018, November). Safe processing method and storage time threshold for consuming of powdered-infant formula based on total plate count test. In IOP Conference Series: Earth and Environmental Science (Vol. 205, No. 1, p. 012033). IOP Publishing.

Nasution, I. K., Lubis, N. D. A., Erwin, I., \& Nusa, M. I. (2018). Cognitive Function Differences based on Hemispheric Lesions of First-Ever Ischemic Stroke Patients. Ethnicity, 31, 44-30. 